\title{
Interpretaties, afbakening en toekomst van BIVIAO
}

\author{
Arco van de Ven
}

SAMENVATTING Het artikel geeft antwoord op de volgende drie vragen. Ten eerste: wat bepaalt de verschillende interpretaties die aan het vak BIV/AO worden gegeven? Ten tweede: hoe verhoudt BIV/AO zich tot andere vakgebieden? En tot slot: in welke richting kan BIV/AO zich in de toekomst ontwikkelen? De verschillende interpretaties van BIV/AO worden verklaard door een analyse van de verschillende doelen die met het vakgebied worden nagestreefd. De relatie met andere vakgebieden wordt ingevuld door een analyse van het paradigma dat ten grondslag ligt aan BIV/AO. De toekomst van het vakgebied BIV/AO ligt in het uitvoeren van empirisch onderzoek in complexere hedendaagse organisaties.

RELEVANTIE VOOR DE PRAKTIJK Er bestaan vele opvattingen over de inhoud en functie van BIV/AO in de praktijk. Het artikel geeft een overzicht van verschillende mogelijke doelen van BIV/AO en de samenhang met andere vakgebieden. Inzicht hierin kan behulpzaam zijn bij discussies over de inhoud, afbakening en samenhang van functies in organisaties op het gebied van BIV/AO.

\section{Inleiding}

Het vak BIV/AO heeft een rijke geschiedenis in Nederland. $\mathrm{BIV} / \mathrm{AO}$ neemt van oudsher een centrale plaats in bij de postinitiële opleidingen, zoals RA (Register Accountant), RC (Register Controller), RE (Register EDP Auditor), RO (Register Operational Auditor) en CPC (Certified Public Controller). Het feit dat het vakgebied op vele opleidingen wordt onderwezen betekent echter niet dat er overeenstemming over de inhoud bestaat. De ontwikkeling van het vakgebied laat vele discussies over de naamgeving en de scope van het vakgebied zien. Van de acht hoogleraren die in 1978 de opdracht aanvaarden om een advies uit te brengen over de naamgeving van het vak, waren er volgens Soeting en Spoor in 1987 nog drie over die met elk met hun eigen afwijkend advies kwamen (2003: 414). Ook na 1987 zijn er nog vele, vaak normatieve, discussies over welke naam het beste bij de gekozen scope past en waarom een bredere of smallere scope nodig is (de Koning, 2000, de Koning, 2004, Emanuels, 2005, Hartman, 1993, Kocks, 1997). In 2006 is er een gezamelijke notitie verschenen van deelnemers van het hooglerarenoverleg BIV waarin een nieuw leerplan met eindtermen werd gepresenteerd. De essentie van de notitie was om het vak terug te brengen tot de kern: het produceren en verstrekken van goede informatie (Van Rietschoten, 2006). Net als Paape (2008: 81) onderken ik nog verschillen van mening met de collega-hoogleraren over de inhoud en kern van ons vakgebied. De eindtermen bieden ook enige mogelijkheid om eigen accenten te leggen (van Rietschoten, 2006). Met het doel een verdere overeenstemming te verkrijgen over de kern en de inhoud van het vak $\mathrm{BIV} / \mathrm{AO}$ wordt in dit artikel een analyse gemaakt van de achterliggende interpretaties van het vak. In plaats van een normatief standpunt in te nemen, zal in dit artikel worden getracht de overeenkomsten en verschillen van de interpretaties te analyseren en te duiden. De verschillende interpretaties van BIV/AO worden in dit artikel opgehangen aan drie verschillende wijzen waarop naar BIV/AO kan worden gekeken. Ten eerste, welke achterliggende doelen worden nagestreefd met de onderwerpen die binnen BIV/AO worden behandeld. Ten tweede, wat is hetgeen dat BIV/AO onderscheidt van andere vakgebieden en ten derde, welke organisatorisch trends/factoren worden meegenomen in de uitwerking van het vakgebied. Tot slot worden op basis van deze analyse aanbevelingen voor opleiding en onderzoek van het vak BIV/AO afgeleid.

\section{Interpretaties van BIV/AO}

Om inzicht te geven in de verschillende manieren waarop inhoud wordt gegeven aan het vakgebied BIV/AO, zal ik proberen de verschillende interpretaties van het vakgebied $\mathrm{BIV} / \mathrm{AO}$ te duiden. De analyse is gebaseerd op een drietal vragen:

1. Zijn er verschillende doelen te onderkennen waarop het vakgebied zich richt?

2. Worden deze doelen ook andere vakgebieden ingevuld en wat is het onderscheidende kenmerk van BIV/AO?

3. Welk invloeden en soorten organisaties worden bij BIV/ AO meegenomen?

\subsection{Verschillende doelen}

Een eerste manier om de verschillende interpretaties van $\mathrm{BIV} / \mathrm{AO}$ te doorgronden, is het nagaan of er verschillende doelen zijn te onderkennen waarop BIV/AO zich richt. In 
deze teleologische benadering wordt gekeken naar welke problematiek de behandelde theorie, technieken en bestpractices tracht op te lossen. In andere woorden: over welke verschillende doelen hebben BIV/AO beoefenaars kennis gegenereerd en toegepast? De indeling die in dit artikel wordt gehanteerd en in het vervolg van het artikel wordt toegelicht, betreft het onderscheid tussen theorievorming gericht op de kwaliteit van (1) informatie, zoals balans en winst- en verliesrekening, (2) het informatiesysteem, (3) informatiemanagement en (4) de organisatie. Deze verschillende doelen zijn schematisch in figuur 1 weergegeven.

Een korte toelichting op de herkomst oorsprong en de consequenties van verschillende doelen.

Doel: informatie (bestuurlijke informatievoorziening)

Het vak BIV/AO is ontstaan vanuit de accountancy, waarbij een oordeel over de betrouwbaarheid van verantwoordingen zoals winst- en verliesrekening en balans moet worden gegeven. Van oudsher is daarom binnen het vak BIV/AO een theorie ontwikkeld over hoe de kwaliteit, met name de betrouwbaarheid, van de informatie kan worden geborgd. De meest bekende theorie is de typologie van Starreveld, die zich vooral richt op het waarborgen van de volledigheid van de opbrengstverantwoording. En natuurlijk het gebruik hierbij van de waardekringloop en controletechnische functiescheiding (Starreveld \& Van Leeuwen, 2007, Starreveld et al., 2004). Maar ook de huidige Sarbanes Oxley Wetgeving, artikel 404, is gericht op de interne beheersing van de betrouwbaarheid van financiële rapportages.

Doel: informatieverzorging (bestuurlijke informatievoorziening/ accounting information systems)

Informatiesystemen dienen als middel om betrouwbare informatie te genereren. De gegevens moesten immers systematisch worden verzameld, vastgelegd, verwerkt en uiteindelijk leiden tot het verstrekken van informatie. De toenemende invloed van automatisering leidde er toe dat het informatiesysteem dat als middel voor de betrouwbare informatie diende, steeds meer als doel werd gezien. De geautomatiseerde gegevensverwerking als doel betekent aandacht voor IT-oplossingen, zoals ERP-systemen. Van het middel om informatie te genereren, kan het informatiesysteem worden gezien als het doel waarover theorie kan worden ontwikkeld. Theorieën die hierbij zijn ontwikkeld in het vakgebied zijn bijvoorbeeld de uitwerkingen van de fasen van de waardekringloop, waarmee referentiemodellen worden gepresenteerd. Hiermee wordt aangegeven hoe de gegevens voor de betreffende functies systematisch kunnen worden verzameld, vastgelegd en worden verstrekt. De beheersmaatregelen om de informatie betrouwbaar te kunnen verstrekken kunnen zo in de

\section{Figuur 1 Mogelijke doelen en middelen van onderzoek AO}

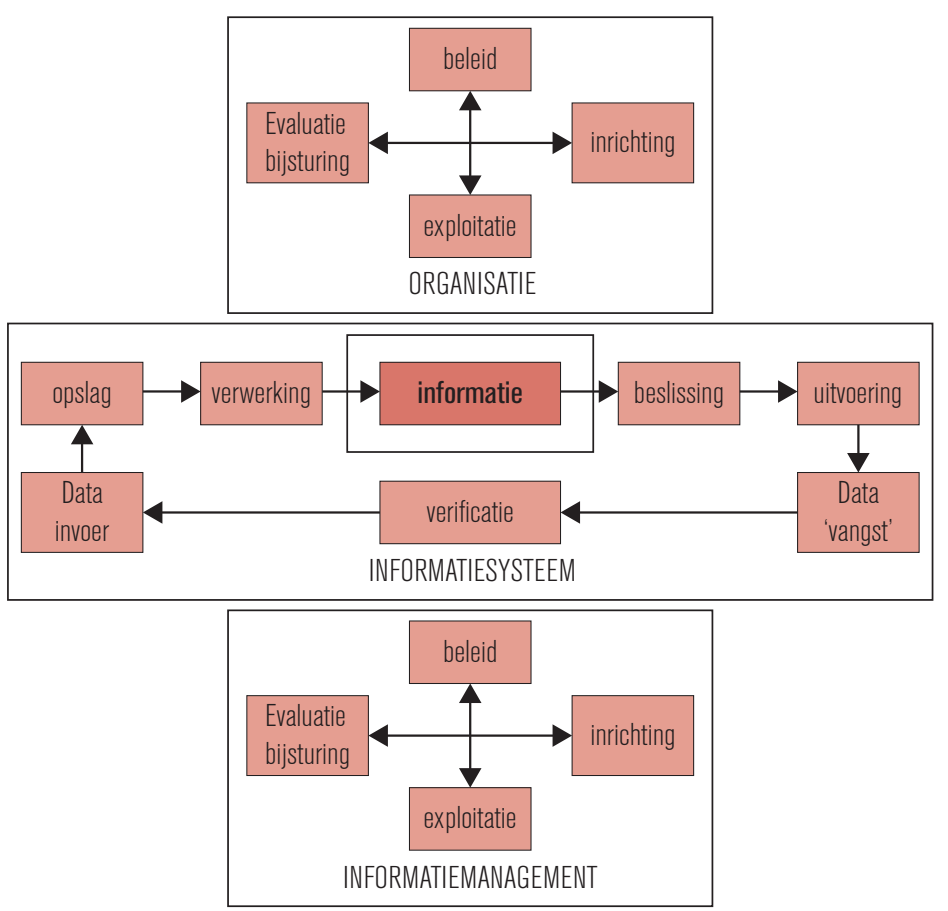

processen worden opgenomen (Starreveld et al., 2004). Ook wordt er in de leerboeken aandacht besteed aan de technische aspecten van het organiseren en management van informatie, zoals ERP-systemen, documentinformatiesystemen, databasemanagementsystemen, XBRL en OLAPtools (Gelinas \& Dull, 2008).

Doel: informatiemanagement (Organisatie van de Informatieverzorging)

Tegenvallende doorlooptijden en kosten van automatiseringsprojecten betekenden meer aandacht voor het sturen en beheersen van de totstandkoming en beheer van de informatiesystemen. Ook hier is een verschuiving mogelijk van doel naar middel. Het doel kwalitatieve hoogwaardige informatiesystemen wordt ingevuld door adequaat informatiemanagement. Onderwerpen die hierbij aan de orde komen zijn bijvoorbeeld informatieplanning, systeemontwikkelingsmethodieken, selectie van softwarepakketten en het beheer van en de implementatie van geautomatiseerde systemen (Hartman, 1993). Aan enkele van deze onderwerpen kan via best-practices zoals COBIT, ITIL en RUP invulling worden gegeven.

Doel: organisatie (Internal Control, Enterprise Risk Management) Naast de verschuiving van middel en doel van informatie, informatiesysteem en informatiemanagement, kan informatie ook worden gezien als een middel voor het nemen van beslissingen en het sturen en beheersen en doen functioneren van de organisatie. De aandacht kan hierbij 
verschuiven van informatie als middel naar het doel waar de informatie voor dient. De behoefte aan een goede interne beheersing van de organisatie kan daarmee als doel van het onderzoek worden gezien en niet de informatie als zodanig. Het waarborgen van een redelijke zekerheid van het gaan realiseren van organisatiedoelstellingen is breder dan het verzorgen van relevante en betrouwbare informatie. Zo stelt Paape dat bijvoorbeeld visie/missie/strategie, leiderschapsstijl en cultuur belangrijke elementen zijn voor het vormen van een oordeel over de beheersing van de organisatie (Paape, 2008: 49). Bij deze ruimere insteek van het vakgebied behoort bijvoorbeeld het behandelen van best-practices zoals COSO-ERM.

In figuur 2 zijn de besproken interpretaties in tabelvorm weergegeven.

\section{Figuur 2 Verschillende doelstellingen van BIV/AO}

\begin{tabular}{|l|l|l|}
\hline Object & Benaming BIVIAO & $\begin{array}{l}\text { Theorie/methodieken/ } \\
\text { tools en templates }\end{array}$ \\
\hline Informatie & $\begin{array}{l}\text { Bestuurlijke } \\
\text { Informatievoorziening }\end{array}$ & $\begin{array}{l}\text { Typologie van Starreveld, SOX, } \\
\text { Controletechnische } \\
\text { functiescheiding }\end{array}$ \\
\hline $\begin{array}{l}\text { Informatie- } \\
\text { systeem }\end{array}$ & $\begin{array}{l}\text { Bestuurlijke } \\
\text { informatieverzorging/ } \\
\text { Accounting Information } \\
\text { Systems }\end{array}$ & $\begin{array}{l}\text { Fasen van de waardekringloop, } \\
\text { Cycle approach, ERP, DIS, } \\
\text { OLAP, XBRL. }\end{array}$ \\
\hline $\begin{array}{l}\text { Informatie } \\
\text { management }\end{array}$ & $\begin{array}{l}\text { Organisatie van de } \\
\text { Informatieverzorging }\end{array}$ & COBIT, ITIL, RUP \\
\hline Organisatie & $\begin{array}{l}\text { Interne Beheersing/ } \\
\text { Enterprise Risk } \\
\text { Management }\end{array}$ & COSO ERM \\
\hline
\end{tabular}

\subsection{Doelen, BIV/AO en andere vakgebieden}

De vraag is echter wel of de genoemde doelen (objecten van onderzoek) niet door andere vakgebieden worden ingevuld. En indien dit het geval is, wat is dan het onderscheidend vermogen van BIV/AO? Als de genoemde doelen van onderzoek worden afgezet tegen andere vakgebieden, dan valt inderdaad op dat aangrenzende vakgebieden zich op dezelfde doelen richten. In figuur 3 zijn vakgebieden onderkend die zich op hetzelfde object van onderzoek richten.

\section{Figuur 3 Onderzoeksobjecten en vakgebieden}

\begin{tabular}{|l|l|l|}
\hline Object & AO & $\begin{array}{l}\text { Andere } \\
\text { vakgebieden }\end{array}$ \\
\hline Informatie & $\begin{array}{l}\text { Bestuurlijke } \\
\text { Informatievoorziening }\end{array}$ & Management accounting \\
\hline $\begin{array}{l}\text { Informatie- } \\
\text { systeem }\end{array}$ & $\begin{array}{l}\text { Bestuurlijke } \\
\text { informatieverzorging/ } \\
\text { Accounting Information } \\
\text { Systems }\end{array}$ & Informatiesystemen \\
\hline $\begin{array}{l}\text { Informatie } \\
\text { management }\end{array}$ & $\begin{array}{l}\text { Organisatie van de } \\
\text { Informatieverzorging }\end{array}$ & Informatiemanagement \\
\hline Organisatie & $\begin{array}{l}\text { Interne Beheersing/Enterprise } \\
\text { Risk Management }\end{array}$ & Management control \\
\hline
\end{tabular}

Het is logisch dat het toe-eigenen van onderwerpen van andere vakgebieden een punt is dat in discussies met collega's uit Management Accounting vaak opkomt. In de eindtermen BIV voor de accountantsopleiding staan kennisdomeinen genoemd, die ook voor andere vakgebieden (Management Accounting en Informatiemanagement) van toepassing zijn.

'Bij elk van die invalshoeken wordt vanuit een bepaalde invalshoek naar de verschillende kennisdomeinen gekeken. Bij BIV gebeurt dit vanuit de optiek van de bestuurlijke informatieverzorging en de rol hiervan bij de beheersing van organisaties' (CEA, 2008: 24)

De dominante en gebruikelijke definitie van BIV geeft hierbij weinig aanknopingspunten om de optiek van BIV te bepalen.

'Alle activiteiten met betrekking tot het systematisch verzamelen, vastleggen en verwerken van gegevens, gericht op het verstrekken van informatie ten behoeve van het besturen-inengere-zin (kiezen uit alternatieve mogelijkheden), het doen functioneren en het beheersen van een huishouding, en ten behoeve van de verantwoordingen die moeten worden afgelegd' (Starreveld et al., 2002: 3)

Maar echt onderscheidend is deze definitie niet, gegeven bijvoorbeeld de definitie van Kaplan van het vak Management Accounting. Deze vertoont toch zeer veel overeenkomsten met de gegeven BIV-definitie.

'A system that collects, classifies, summarizes, analyzes, and reports information that will assist managers in their decisionmaking and control activities' (Kaplan, 1982: 1) 
Het verschil tussen BIV/AO en de andere vakgebieden moet derhalve liggen in de invalshoek waarmee naar de onderzoeksobjecten wordt gekeken. Inderdaad wordt het bestaan van een vakgebied en onderscheid met andere vakgebieden mede bepaald door de groep van beroepsbeoefenaren. Wetenschapsontwikkeling kan volgens Kuhn (1996:176) niet worden losgezien van de scientific community waarin het zich ontwikkeld. De gedeelde opvattingen binnen een dergelijke wetenschapsgemeenschap vormen een paradigma, dat veelal een onbesproken richting geeft aan het gedrag van individuele leden van de groep. De eigenschappen van een dergelijke gemeenschap worden door Kuhn als volgt omschreven:

'A scientific community consists, on this view, of the practitioners of a scientific speciality. To an extent unparalleled in most other fields, they have undergone similar educations and professional initiations; in the process they have absorbed the same technical literature and drawn many of the same lessons from it' (Kuhn, 1996:177)

Dat BIV/AO-onderzoekers een dergelijk gemeenschap vormen, is mijns inziens duidelijk. BIV/AO wordt gepositioneerd als een accountancyvak, dat is voortgekomen uit de accountantscontrole (Kocks, 2003, Vaassen, 2000, Vaassen, 2002) en is sterk praktijkgeoriënteerd (Kocks, 2003, Vaassen, 2000). Dit is nog steeds waar te nemen aan de huidige hoogleraren BIV/AO, zij allen hebben een opleiding tot RA genoten en allen werken of hebben gewerkt bij één van de grote accountantskantoren. Zo heeft het tijdschrift MAB een afzonderlijke sectie BIV met een afzonderlijke groep redacteuren. Dit betekent dat momenteel BIV/AO een te onderscheiden vakgebied is dat zich onderscheidt van andere vakgebieden met een afzonderlijke groep van onderzoekers.

De achtergrond van de onderzoekers heeft volgens Kuhn dus een belangrijke invloed op de theorievorming in het vakgebied en hierbij speelt de invalshoek waarmee naar het object van onderzoek wordt gekeken een belangrijke rol. Dit kan nader worden ingevuld door te kijken aan welke benadering binnen het vakgebied BIV/AO met name aandacht wordt besteed. Een onderscheid dat hierbij nuttig kan zijn is de indeling die Vickers (1992) aanbrengt tussen 'negative contol' en 'positive control'. Bij 'negatieve control' staat het voorkomen van negatieve gebeurtenissen centraal en bij 'positieve control' draait het om de wijze waarop organisatie hun doelstellingen kunnen behalen. Populair gesteld, het verschil tussen het gaspedaal en de rem. Het verschil tussen het motiveren van medewerkers om de strategieën te implementeren en het voorkomen dat er risico's optreden en tot ongewenste schade leiden. Dit laatste sluit goed aan bij de accountancyberoepsgroep. Het zijn van vertrouwensman van het maatschappelijk verkeer, waarbij verklaringen worden afgegeven over de getrouwheid van verantwoordingen, benadrukt de invalshoek van het kijken naar wat de bedreigingen zijn in plaats van wat de kansen zijn.

Wat betekent een dergelijke demarcatie nu voor de behandeling van onderwerpen in het vakgebied BIV/AO in relatie tot andere vakgebieden? Negative control vertaalt zich bij de doelen van BIV/AO naar het leggen van de nadruk op de betrouwbaarheid en continuiteit van het bereiken van de verschillende doelen/objecten. Dit in tegenstelling tot de andere vakgebieden die van nature meer aandacht besteden aan de effectiviteit en de efficiency. Bij het doel informatie is het met name het vakgebied Management Accounting dat invulling geeft aan wat relevante informatie is op basis van performance measurement en cost accounting. Bij de informatieverzorging wordt vanuit de vakgebieden Logistiek, Kwaliteitsmanagement en Informatiesystemen invulling gegeven aan methoden en technieken om bedrijfs- en informatieprocessen te optimaliseren. Het vak informatiemanagement richt zich op de strategische inzet van informatietechnologie en het realiseren van informatiesystemen. Met betrekking tot de beheersing van organisaties richt Management Control zich op het motiveren van management om de strategie van de organisatie te implementeren. Om te illustreren tot wat voor verschillende invullingen dit kan leiden tussen BIV/AO en andere vakgebieden zijn in figuur 4 voorbeelden opgenomen van verschillende methodieken en onderwerpen.

\subsection{Beelden van organisaties}

Een derde factor die de verschillende invullingen van BIV/ AO bepaalt, betreft het beeld van organisaties dat als uitgangspunt in het vakgebied wordt meegenomen. Organisaties zijn complex en daarom moet er gewerkt worden met een vereenvoudigd beeld van organisaties. De Koning (2008) gebruikt metaforen van Morgan om verschillende zienswijzen te duiden. Metaforen zoals machines, hersenen, culturen, politieke systemen, psychische gevangenissen, voortdurende verandering en middel tot overheersing geven een ander beeld van organisaties en leiden tot verschillende theorievorming om de verschillende doelen te realiseren. Uit contingentieonderzoek blijkt dat er geen standaard beste wijze van organiseren is, maar dat dit afhangt van diverse factoren, zoals omvang, onzekerheid, strategie en technologie (Donaldson, 2001). De toepasbaarheid van de theorievorming hangt samen met welke organisatiebeelden als uitgangspunt worden gehanteerd en met welke factoren rekening wordt gehouden.

\section{BIV/AO interpretaties en het vak BIV}

Welke consequenties kunnen uit deze verschillende interpretaties van BIV/AO worden afgeleid? De interpretaties worden in deze paragraaf afgezet tegen de gezamenlijke notitie van de 
Figuur 4 Onderzoeksobjecten, vakgebieden en theorieën

\begin{tabular}{|l|l|l|}
\hline Doel & BIVIAO & Andere vakgebieden \\
\hline Informatie & $\begin{array}{l}\text { Theorievorming op het gebied van betrouwbaarheid, continuïteit van } \\
\text { informatie: } \\
\text { Typologie van Starreveld, SOX, Controletechnische functiescheiding }\end{array}$ & $\begin{array}{l}\text { Management accounting: theorievorming op het gebied van relevante } \\
\text { informatie: } \\
\text { BBSC, ABC, Target Costing, Critical Success Factors }\end{array}$ \\
\hline $\begin{array}{l}\text { Informatie- } \\
\text { systeem }\end{array}$ & $\begin{array}{l}\text { Theorievorming op het gebied van de beheersing (betrouwbaarheid en } \\
\text { continuïteit) van informatieverzorging (processen): } \\
\text { 0.a. Fasen van de waardekringloop, Cycle approach, }\end{array}$ & $\begin{array}{l}\text { Theorievorming op het gebied van effectiviteit en efficiency van } \\
\text { bedrijfsprocessen en de daaraan gekoppelde informatieverzorging } \\
\text { 0.a. Business Process Redesign, Logistiek, Methoden en technieken } \\
\text { van gegevensopslag }\end{array}$ \\
\hline $\begin{array}{l}\text { Informatie } \\
\text { management }\end{array}$ & $\begin{array}{l}\text { Theorievorming op gebied van de beheersing (betrouwbaarheid en } \\
\text { continuïteit) van de totstandkoming, gebruik en beheer van } \\
\text { informatiesystemen: } \\
\text { 0.a. COBIT, ITIL, RUP }\end{array}$ & $\begin{array}{l}\text { Theorievorming op gebied van de effectiviteit en efficiency van de } \\
\text { totstandkoming, gebruik en beheer van informatiesystemen: } \\
\text { o.a.Enterprise Architecture, Systeemontwikkelings-methoden, }\end{array}$ \\
\hline Organisatie & $\begin{array}{l}\text { Theorievorming op het gebied van het voorkomen van ongewenste } \\
\text { negatieve gebeurtenissen: } \\
\text { o.a. COSO ERM }\end{array}$ & $\begin{array}{l}\text { Theorievorming op het gebied van het motiveren van managers om de } \\
\text { strategie te implementeren. } \\
\text { o.a. Levers of Control, EVA, INK-model, Beyond Budgeting }\end{array}$ \\
\hline
\end{tabular}

hoogleraren BIV uit 2006 (van Rietschoten, 2006) en de afgeleide eindtermen voor de RA opleiding (CEA, 2008).

\subsection{Verschillende doelen}

Terug naar de kern, 'het produceren en verstrekken van goede informatie' was het doel van het nieuwe leerplan. Deze kern sluit aan bij de genoemde doelen informatie en informatiesysteem. De behandelde eindtermen en kennisdomeinen geven echter een ander beeld. Onderwerpen genoemd in de eindtermen 'Effectiviteit en efficiency van bedrijfsvoering', 'Risicomanagement' en 'Informatie- en Communicatietechnologie' hebben een bredere doelstelling dan het 'produceren en verstrekken van goede informatie'. De genoemde interpretaties zijn allemaal terug te vinden in het eindtermen voor de RA-opleiding.

\subsection{Afbakening met andere vakken}

Hoe is de afbakening met andere vakken geregeld? In de eindtermen wordt aangegeven dat de genoemde kennisdomeinen ook op andere vakgebieden van toepassing zijn. 'Bij elk van die vakgebieden wordt vanuit een bepaalde invalshoek naar de verschillende kennisdomeinen gekeken. Bij BIV gebeurt dit vanuit de optiek van de bestuurlijke informatieverzorging en de rol hiervan bij de beheersing van organisaties' (CEA, 2008:24). Deze invalshoek beperkt zich zoals in de vorige paragraaf aangegeven niet alleen tot het produceren en verstrekken van goede informatie. Ook beperkt deze zich niet tot negative control. In de eindtermen van de opleiding tot Registeraccountant zijn bijvoorbeeld ' $\mathrm{K} 4$ Efficiëntie en effectiviteit van de bedrijfsvoering' en ' $\mathrm{K}$ 8 Relevantie van informatie' opgenomen voor BIV/AO (CEA, 2008).

\subsection{Beeld van organisatie}

De Koning (2008: 171) geeft aan dat het beeld van organisaties als machines overheerst in de BIV-literatuur. Dit beeld sluit aan bij de organisatiebeschrijvingen van de landelijke examens van post-initiële accountantsopleidingen. De organisaties in deze opgaven zijn veelal te typeren als mechanistisch (Burns \& Stalker, 1961). Hetgeen aansluit bij de opmerking 'BIV is heel lang gedomineerd door een technocratische aanpak van controls' van de zeven samenstellers van de notitie uit het hooglerarenoverleg (van Rietschoten, 2006). Achterliggende veronderstellingen die de wijze van uitwerking beïnvloeden zijn hierbij:

1. Hoge mate van zekerheid over het wenselijke verloop van de processen in de organisatie;

2. Het primaire proces wordt door de organisatie zelf uitgevoerd, waarbij alleen zaken worden uitbesteed zoals transportactiviteiten;

3. De organisatie heeft een functionele organisatiestructuur, waardoor functiescheiding eenvoudig te koppelen is aan de bestaande structuur;

4. De werkzaamheden worden bepaald door instructies en beslissingen van de chef;

5. Door de lage mate van onzekerheid is er sprake van een intended strategie en kan deze worden gekoppeld aan meerjarenplannen en jaarplannen en begrotingen.

\section{Aanbevelingen onderwijs BIV/AO}

Welke aanbevelingen kunnen worden afgeleid uit de bovenstaande analyse? Het vak BIV/AO is breder dan de genoemde kern: produceren en verstrekken van goede informatie. De vraag is of dit nadelig is. De verschillende interpretaties van BIV/AO sluiten elkaar niet uit. Het feit 
dat betrouwbare informatie belangrijk is, zegt natuurlijk niets over het belang van de interne beheersing voor organisaties. Maar een andere nadruk levert zeker een zeer verschillende invulling van het vak op. De wenselijkheid van het benadrukken van betrouwbare informatie is gegeven de recente boekhoudschandalen van Enron, Ahold en Société General te verdedigen. Maar ook de bredere nadruk, interne beheersing, staat door de kredietcrisis en de daaruit voorvloeiende problematiek hoog op de corporate governance agenda. Eenzelfde redenering kan worden opgezet voor de twee andere doelstellingen.

De opstellers van de notitie uit het hooglerarenoverleg geven aan dat het vak zich in de diepte moet ontwikkelen, niet in de breedte. "Het gaat om het opleiden van specialisten, niet om alleskunners' (Van Rietschoten, 2006). Een mogelijkheid om dit te realiseren ligt in het toespitsen op het eigene van BIV/AO: de bril waarmee naar de wereld wordt gekeken. Het benadrukken van 'negative control'. Naast dat het leidt tot een beperking levert dit bovendien een scherpere afbakening met de aangrenzende vakgebieden op. In de bovenstaande optiek kan de kennis vanuit de aangrenzende vakgbieden hierbij het vertrekpunt zijn. Als voorbeeld kan de Balanced Scorecard dienen. De BIV/ AO-invalshoek zou dan niet zijn welke relevante indicatoren deze dient te bevatten, maar vanuit een risico-invalshoek aan te geven hoe de betrouwbaarheid van deze indicatoren is te waarborgen. En vanuit een bredere BIV/ AO-invalshoek: welke disfunctionele effecten kunnen optreden en welke mogelijkheden er bestaan om deze negatieve invloed te mitigeren.

Wat betekent deze opvatting voor de diverse postinitiële opleidingen? Dit zal leiden tot een differentiatie van het vak $\mathrm{BIV} / \mathrm{AO}$ voor de diverse opleidingen. Bij de RC- en RO-opleidingen worden de vakken Management Accounting \& Control en Informatiemanagement naast het vak BIV/AO gegeven. Het vak BIV/AO kan in deze opleidingen zich dan concentreren op negative control. Voor de RA-opleiding is dit anders. De vakken Management Accounting \& Control en Informatiemanagement behoren niet tot het curriculum en aspecten van positive control kunnen worden opgenomen in het lesprogramma onder BIV/AO.

Het mechanistisch organisatiebeeld is slechts op beperkt deel van organisaties toepasbaar. Dit pleit er voor om de scope van BIV/AO te vergroten door de genoemde uitgangspunten los te laten. Verschillen in uitgangspunten leiden tot een andere invulling van het vakgebied BIV/AO.

Theorieën en vakgebieden zullen altijd modellen van de werkelijkheid zijn. Abstracties zijn nodig en er dient een keuze gemaakt worden welke invloeden worden meege- nomen en welke niet. Deze keuze bepaalt sterk de inhoud van het vak BIV/AO. Het gaat de scope van dit artikel te buiten om de impact van moderne trends op de verschillende onderzoeksobjecten uit te werken, maar hier volgen drie voorbeelden om de mogelijk vergaande invloed te illustreren:

1. Organisaties in een omgeving met een hoge mate van onzekerheid hebben andere beheersingsmechanismen (Simons, 1995; Speklé, 2001). De standaard klassieke BIV/ AO uitwerking, waarin een taakstellende begroting en standaard procedures, richtlijnen en verbandcontroles een belangrijke rol spelen, is in een situatie van hoge onzekerheid onvoldoende om invulling te geven aan een adequate beheersing van de organisatie. In situaties van hoge onzekerheid is het moeilijk zo niet onmogelijk om normatief aan te geven hoe de processen moeten verlopen. Het standaardiseren van processen met daarin opgenomen maatregelen om de betrouwbaarheid van de informatie te borgen wordt daarmee lastig. Standaardisatie kan in deze gevallen zelfs negatief werken op de motivatie van medewerkers;

2. Andere organisatiestructuren, zoals een procesgerichte indeling, in combinatie met het werken in teamverband, leveren beperkingen op ten opzichte van de mogelijkheden en effectiviteit van controle-technische functiescheidingen;

3. Strategievorming, zoals beschreven in the New Age of Innovation van Prahalad en Krishnan (2008), waarbij de individuele klant veel meer centraal komt te staan en dienstverlening veel meer in een netwerk van samenwerkingsverbanden zal plaatsvinden, leidt tot een geheel andere invulling van het vakgebied BIV/AO dan een invulling op basis van de beschreven klassieke organisatie.

Het beperken van BIV/AO tot negative control geeft ruimte en mogelijkheid om meer aandacht te besteden aan complexe organisaties in een dynamische omgeving en zo de gewenste diepgang te bereiken.

\section{Aanbevelingen onderzoek BIV/AO}

De wetenschappelijkheid van het vakgebied BIV/AO is de laatste jaren in twijfel getrokken. Zo is bijvoorbeeld op de Erasmus Universiteit de leerstoel verdwenen en het vak onder Management Accounting \& Control geschoven. De argumentatie hierbij is dat het internationaal geen wetenschappelijke discipline is en er nauwelijks empirisch onderzoek wordt verricht. Van AO wordt gesteld dat het meer een praktijkvak is dan een wetenschap. Het beeld dat naar voren komt, is dat het vakgebied is gebaseerd op normatieve theorieën, ondersteund met best-practices en richtlijnen van beroepsorganisaties en dat er geen empirisch onderzoek 
aanwezig is en wellicht nog belangrijker: dat empirisch onderzoek ook niet nodig en wenselijk zou zijn.

Een vergelijking tussen $\mathrm{BIV} / \mathrm{AO}$ en Management Accounting valt te maken. Binnen het vak Management Accounting heeft ook een beweging plaatsgevonden van normatief onderzoek naar empirisch onderzoek. Van de Poel typeert de normatieve invulling als de 'oude bedrijfseconomie', een benadering die volgens hem veel weg had van de Oostenrijkse benadering. 'Langs deductieve weg praktische oplossingen afleiden uit een plausibel, generiek model van de werkelijkheid. Het debat tussen wetenschappers ging dan ook over de juiste keuze van het grondmodel en de correcte afleiding van implicaties.' (1999:651) Veel empirisch onderzoek was hier niet voor nodig. Dit betekende discussies en publicaties over de definities van kosten en kostprijs. Momenteel neemt in het vakgebied Management Accounting empirisch onderzoek een centrale plaats in. Dit empirisch onderzoek strekt zich uit van kwantitatief onderzoek met behulp van vragenlijsten, experimenten en database onderzoek tot en met gevalsstudies. Een verschuiving van de nadruk van hoe het moet, naar begrijpen en verklaren hoe het gaat.

Binnen BIV/AO is een dergelijke verschuiving ook noodzakelijk en mogelijk. De geformuleerde onderzoeksobjecten in paragraaf 2 in combinatie met de risicobenadering uitgewerkt in paragraaf 3 en de invloed van genoemde ontwikkelingen in paragraaf 4 zijn interessante gebieden voor wetenschappelijk onderzoek. Voor voorbeelden van recent wetenschappelijk empirisch onderzoek op dit BIV/ $\mathrm{AO}$ terrein wordt verwezen naar van de Ven (2008).

\section{Conclusie}

In dit artikel is getracht de verschillende invullingen en opvattingen over het vak BIV/AO te duiden. De volgende drie vragen zijn in het artikel beantwoord.

Wat bepaalt de verschillende interpretaties van het vak BIV/AO? De verklaring voor de verschillende interpretaties van het vak kan worden gegeven door de inhoud van de stof te rela- teren aan de verschillende doelen die kunnen worden nagestreefd. Het onderkennen van de verschillende doelen betekent dat er verschillende deelgebieden binnen het vak BIV/AO kunnen worden onderkend. De deelgebieden vullen elkaar aan en kunnen naast elkaar bestaan. Het maken van keuze voor curricula is daarom geen principiële kwestie. Het draait met name om het inschatten van het belang en de urgentie van de onderliggende doelstellingen.

Hoe verhoudt BIV/AO zich tot andere vakgebieden? Met betrekking tot de afbakening van BIV/AO ten opzichte van andere vakgebieden, wordt gepleit om het vak te beperken tot het aanwezige paradigma in de beroepsgroep. BIV/AO kan zich het beste concentreren op betrouwbaarheid en continuïteit van informatie(systemen) en op mogelijkheden tot het afwenden of beperken van risico's.

In welke richting kan BIV/AO zich in de toekomst ontwikkelen? Veel theorie in het vakgebied BIV/AO is nog gestoeld op 'mechanistische' organisaties. Het loslaten van deze veronderstellingen maken dat het vakgebied andere theorieën en verklaringen nodig heeft. Het uitgaan van gestileerde mechanistische organisaties met een hoge mate van voorspelbaarheid en lage complexiteit maakt normatieve theorie mogelijk. Empirisch onderzoek naar juist organisaties in hun natuurlijke omgeving, kan een verklaringen bieden over hoe BIV/AO zich in de praktijk voltrekt. En inzicht bieden hoe betrouwbaarheid, continuïteit en interne beheersing in meer complexe hedendaagse organisaties verlopen.

Prof. dr. A.C.N. van de Ven RA is hoogleraar Bestuurlijke Informatievoorziening aan TiasNimbas Business School van de Universiteit van Tilburg en partner van ACN Management consultants.

\section{Literatuur}

- Burns, T. en G. M. Stalker (1961), The management of innovation, Tavistock Publications: London.

- Cea (2008), 'Eindtermen theoretische accountantsopleiding'. CEA-inf 7423, no. versie 2008-1.

- Donaldson, L. (2001), The contingency theory of organizations, Sage Publications: Thousand Oaks.

- Emanuels, J. (2005), Interne beheersing: In control of in de krant - beschouwing over een crisis Universiteit van Groningen: Groningen. —Gelinas, U. J. en R. B. Dull (2008), Accounting information systems, Thomson South-Western: Mason.

- Hartman, W. (1993), Organisatie van de informatieverzorging, CODIS: Rotterdam.

- Kaplan, R. S. (1982), Advanced management accounting, Prentice Hall International Editions: Englewood Cliffs.
Kocks, H. C. (2003), De relevantie van BIV voor accountant en controller. Maandblad Accountancy en Bedrijfseconomie, vol. 77, no. mei, pp. 225-235.

- Koning, W. F. de (2000), Bestuurlijke informatieverzorging, in het bijzonder informatiecontrole, Nyenrode University Press: Nyenrode.

- Koning, W. F. de (2004), Bestuurlijke informatieverzorging of interne beheersing? 
Maandblad Accountancy en Bedrijfseconomie vol. 78, no. 7/8, pp. 343-347.

- Koning, W. F. de (2008), Visies op interne beheersing. Maandblad Accountancy en Bedrijfseconomie, vol. 82, no. 4, pp. 170-177.

- Kuhn, T. S. (1996), The structure of scientific revolutions third edn., The University of Chicago Press: Chicago,

- Paape, L. (2008), 'in control' verklaringen: Gebakken lucht of een te koesteren fenomeen?, Nyenrode business universiteit: Nyenrode.

- Prahalad, C. K. en M. S. Krishnan (2008),

The new age of innovation - driving co-created value through global networks, Mc GrawHill: New York.

- Poel, J. H. R. van de (1999), 'En nu allemaal! Management accounting-onderzoek als sociaal systeem'. Maandblad Accountancy en Bedrijfseconomie, vol. 73, no. 12, pp. 650-658. - Rietschoten, P. van (2006), 'Terug naar de kern'. De Accountant, vol. 112, maart.
- Simons, R. (1995), 'Control in an age of empowerment'. Harvard Business Review, vol. 73, no. 2, pp. 80-88.

— Soeting, R. en L. Spoor (2003), 'COSO na 10 jaar, A0 na 100 jaar'. Maandblad Accountancy en Bedrijfseconomie, vol. 77, no. 9, pp. 408415.

- Speklé, R. F. (2001), 'Explaining management control structure variety: A transaction cost economics perspective'. Accounting, Organizations \& Society, vol. 26, no. 4/5, pp. 419-441.

- Starreveld, R. W. en 0. C. Van Leeuwen (2007), Bestuurlijke informatieverzorging 2b typologie van de bedrijfshuishoudingen, WoltersNoordhoff: Groningen/Houten.

Starreveld, R. W., O. C. Van Leeuwen en H. Van Nimwegen (2002), Bestuurlijke informatieverzorging- deel 1: Algemene grondslagen, Stenfert Kroeze: Groningen/ Houten.
Starreveld, r. W., O. C. Van Leeuwen and H. Van nimwegen (2004), Bestuurlijke informatieverzorging $2 a$ - fasen van de waardekringloop, Stenfert Kroeze: Groningen/ Houten.

- Vaassen, E. H. J. (2000), 'Een onderzoeksagenda voor biv/ao'. Maandblad Accountancy en Bedrijfseconomie, vol. 74, no. oktober, pp. 424-432.

- Vaassen, E. H. J. (2002), Accounting information systems: A managerial approach, John Wiley \& Sons: Chichester.

-Ven, A. C. N. van de (2008), Administratieve organisatie; praktisch relevant maarook wetenschappelijk interessant?, Oratie, Drukkerij Universiteit van Tilburg: Tilburg.

- Vickers, G. (1992), 'Stability, control and choice', in C. Emmanuel \& D. Otley (eds), Readings in accounting for management control, Chapman \& Hall: London. 